EDITORIAL

\title{
Diámetro abdominal sagital: un indicador de grasa visceral que se debe tener en cuenta en la práctica clínica
}

\section{Sagittal Abdominal Diameter: a Visceral Fat Indicator That Should Be Taken Into Account in Clinical Practice}

\author{
Iva Marques-Lopes* \\ Facultad de Ciencias de la Salud y del Deporte, Universidad de Zaragoza, Huesca, España
}

Recibido el 3 de octubre de 2012; aceptado el 30 de octubre de 2012

La distribución de la grasa acumulada puede tener un predominio superior, denominada obesidad central o androide, en la que la grasa se acumula sobre todo en la región cervical, el tronco y la región supraumbilical y aumenta también de manera importante la grasa abdominal profunda o visceral $^{1,2}$. La obesidad abdominal es un componente importante del síndrome cardiometabólico, y hay evidencia científica firme de asociación independiente de otros factores de riesgo con el infarto, el ictus, otras enfermedades cardiovasculares, complicaciones metabólicas y mortalidad general ${ }^{3-6}$.

Actualmente los métodos de referencia para el estudio de la grasa depositada a nivel visceral o intraabdominal son las técnicas de imagen como la tomografía computarizada (TC), la resonancia magnética (RM) y la absorciometría de rayos $X$ de doble energía (DEXA $)^{7}$. Sin embargo, son métodos caros y algunos son invasivos $y$, por ello, carentes de aplicación clínica y epidemiológica. Las medidas antropométricas indirectas han mostrado gran aplicación en la práctica clínica y en epidemiología, por ser sencillas, baratas y no invasivas $^{8}$.

El perímetro de la cintura (PC), más que el índice cintura/cadera (ICC), hasta ahora se ha demostrado como medida simple, barata y efectiva para evaluar el grado de adiposidad abdominal, con una excelente correlación con las técnicas de imagen ${ }^{9}$ y muy asociada con la mortalidad general, las complicaciones metabólicas y el riesgo cardiovascu-

*Autor para correspondencia.

Correo electrónico: imarques@unizar.es (I. Marques-Lopes). $\operatorname{lar}^{10}$. De hecho, entre los criterios de definición de síndrome metabólico adoptados por organizaciones nacionales e internacionales, se incluyen los puntos de corte de esta medida ${ }^{11}$.

Durante los últimos años se viene prestando más atención al diámetro abdominal sagital (DAS). Aunque hasta ahora haya sido una medida menos utilizada y conocida en la práctica clínica diaria, se está consolidando como buen indicador antropométrico de la adiposidad abdominal visceral, y es un mejor marcador predictivo de las complicaciones metabólicas, cardiovasculares y de mortalidad general que el ICC $9,12,13$. En algunos estudios, se ha observado que el DAS es incluso mejor predictor de síndrome metabólico que el PC para dislipemia, hipertensión arterial, resistencia insulínica ${ }^{14-16}$, algunas enfermedades cardiovasculares (ECV) y muerte súbita ${ }^{17}$. En otros estudios, sin embargo, no se observaron ventajas del DAS frente al PC ${ }^{18,19}$.

Pese a ser un indicador antropométrico prometedor, actualmente hay diferentes criterios en el protocolo de medición, en concreto respecto el punto anatómico de toma del diámetro, por lo que aún se carece de una metodología estandarizada y validada, lo que dificulta la comparación de los resultados de diferentes estudios ${ }^{8}$. Con relación a los puntos de corte, se carece igualmente de valores consensuados internacionalmente. En uno de los estudios más importantes dedicados a establecer puntos de corte, se cita el valor de $22 \mathrm{~cm}$ como punto de corte para la identificación de sujetos metabólicamente obesos, especialmente en varones, en quienes esta cifra se correlacionó de manera muy 
significativa con los factores de riesgo metabólicos y la $\mathrm{ECV}^{20}$. En España, se cita el valor de $25 \mathrm{~cm}$ como valor de riesgo metabólico ${ }^{21,22}$.

El DAS puede ser, en combinación con otras medidas antropométricas, un complemento o incluso una alternativa para estimar la grasa visceral y el riesgo de padecer alteraciones relacionadas con esta. Su utilidad en la práctica clínica se verá incrementada y consolidada cuando se disponga de los protocolos de medición y los valores de corte estandarizados y validados.

\section{Bibliografía}

1. Salas-Salvadó J, Rubio MA, Barbany M, Moreno B; Grupo Colaborativo de la SEEDO. Consenso SEEDO 2007 para la evaluación del sobrepeso y obesidad y el establecimiento de criterios de intervención terapéutica. Med Clin (Barc). 2007;128:184-96.

2. Basulto J, Manera M, Baladia E. Postura del GREP-AEDN: la obesidad como enfermedad. Act Diet. 2008;12:98-9.

3. Chen HJ, Bai CH, Yeh WT, Chiu HC, Pan WH. Influence of metabolic syndrome and general obesity on the risk of ischemic stroke. Stroke. 2006;37:1060-4.

4. Cabrera MA, Gebara OC, Diament J, Nussbacher A, Rosano G, Wajngarten $M$. Metabolic syndrome, abdominal obesity, and cardiovascular risk in elderly women. Int J Cardiol. 2007; 114:224-9.

5. Gami AS, Witt BJ, Howard DE, Erwin PJ, Gami LA, Somers VK, et al. Metabolic syndrome and risk of incident cardiovascular events and death: a systematic review and meta-analysis of longitudinal studies. J Am Coll Cardiol. 2007;49:403-14.

6. Jacobs EJ, Newton CC, Wang Y, Patel AV, McCullough ML, Campbell PT, et al. Waist circumference and all-cause mortality in a large US cohort. Arch Intern Med. 2010;170:1293-301.

7. Ross R. Advances in the application of imaging methods in applied and clinical physiology. Acta Diabetol. 2003;40 Suppl $1: S 45-50$.

8. Cornier MA, Després JP, Davis N, Grossniklaus DA, Klein S, Lamarche B, et al; American Heart Association Obesity Committee of the Council on Nutrition; Physical Activity and Metabolism; Council on Arteriosclerosis; Thrombosis and Vascular Biology; Council on Cardiovascular Disease in the Young; Council on Cardiovascular Radiology and Intervention; Council on Cardiovascular Nursing, Council on Epidemiology and Prevention; Council on the Kidney in Cardiovascular Disease, and Stroke Council. Assessing adiposity: a scientific statement from the american heart association. Circulation. 2011;124:1996-2019.

9. Pouliot MC, Després JP, Lemieux S, Moorjani S, Bouchard C, Tremblay A, et al. Waist circumference and abdominal sagittal diameter: best simple anthropometric indexes of abdominal visceral adipose tissue accumulation and related cardiovascular risk in men and women. Am J Cardiol. 1994;73:460-8.
10. De Koning L, Merchant AT, Pogue J, Anand SS. Waist circumference and waist-to-hip ratio as predictrs of cardiovascular events: meta-regression analysis of prospective studies. Eur Heart J. 2007;28:850-6.

11. Expert Panel on Detection, Evaluation, and Treatment of High Blood Cholesterol in Adults. Executive Summary of The Third Report of The National Cholesterol Education Program (NCEP) Expert Panel on Detection, Evaluation, And Treatment of High Blood Cholesterol In Adults (Adult Treatment Panel III). JAMA. 2001;285:2486-97.

12. Iribarren C, Darbinian JA, Lo JC, Fireman BH, Go AS. Value of the sagittal abdominal diameter in coronary heart disease risk assessment: cohort study in a large, multiethnic population. Am J Epidemiol. 2006;164:1150-9.

13. Sampaio LR, Simões EJ, Assis AM, Ramos LR. Validity and reliability of the sagittal abdominal diameter as a predictor of visceral abdominal fat. Arq Bras Endocrinol Metabol. 2007;51:980-6.

14. Risérus U, Arnlöv J, Brismar K, Zethelius B, Berglund L, Vessby B. Sagittal abdominal diameter is a strong anthropometric marker of insulin resistance and hyperproinsulinemia in obese men. Diabetes Care. 2004;27:2041-6.

15. Hoenig MR. MRI sagittal abdominal diameter is a stronger predictor of metabolic syndrome than visceral fat area or waist circumference in a high-risk vascular cohort. Vasc Health Risk Manag. 2010;6:629-33.

16. Nakata K, Choo J, Hopson MJ, Ueshima H, Curb JD, Shin C, et al. Stronger associations of sagittal abdominal diameter with atherogenic lipoprotein subfractions than waist circumference in middle-aged US white and Japanese men. Metabolism. 2010;59:1742-51.

17. Empana JP, Ducimetiere $P$, Charles MA, Jouven X. Sagittal abdominal diameter and risk of sudden death in asymptomatic middle-aged men: the Paris Prospective Study I. Circulation. 2004;110:2781-5.

18. Hwu CM, Hsiao CF, Sheu WH, Pei D, Tai TY, Quertermous T, et al. Sagittal abdominal diameter is associated with insulin sensitivity in Chinese hypertensive patients and their siblings. J Hum Hypertens. 2003;17:193-8.

19. Mukuddem-Petersen J, Snijder MB, Van Dam RM, Dekker JM, Bouter LM, Stehouwer CD, et al. Sagittal abdominal diameter: no advantage compared with other anthropometric measures as a correlate of components of the metabolic syndrome in elderly from the Hoorn Study. Am J Clin Nutr. 2006;84: 995-1002.

20. Riserus U, De Faire L, Berglund ML. Hellenius. Sagittal abdominal diameter as a screening tool in clinical research: cutoffs for cardiometabolic risk. J Obes. 2010;pii:757939.

21. Barbany M, Foz M. Obesity: concept, classification and diagnosis. An Sist Sanit Navar. 2002;25 Suppl 1:7-16.

22. Bellido GD, Carreira AJ, Soto GA, Martínez OM. Ánalisis de la composición corporal. En: Martínez de Victoria E, Maldonado J, coordinadores; Gil A, editor. SENPE. Tratado de nutrición. Vol. 3. Nutrición humana en el estado de salud. Madrid: Médica Panamericana; 2010. 